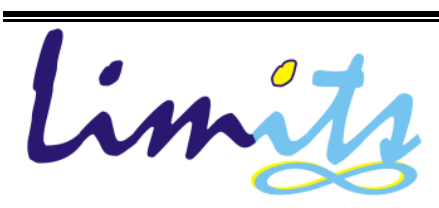

J. Math. and Its Appl.

E-ISSN: 2579-8936

P-ISSN: $1829-605 \mathrm{X}$

Vol. 15, No. 2, Nopember 2018, 127-140

\title{
Model Bayesian Hirarki Curah Hujan Untuk Menentuan Return Level Pendekatan Peaks Over Threshold
}

\author{
Soehardjoepri ${ }^{1}$, Farida AW. ${ }^{2}$, Retno Palupi ${ }^{3}$ \\ ${ }^{123}$ Departemen Matematika ITS Surabaya Indonesia \\ e-mail: djoepri.its@gmail.com, agustini.farida54@gmail.com
}

\begin{abstract}
Abstrak
Curah hujan ekstrim merupakan kondisi curah hujan yang sangat tinggi atau sangat rendah. Salah satu ilmu yang mempelajari kejadian ekstrim adalah pendekatan Peaks Over Threshold (POT) dengan pola distribusi mengikuti Generalized Pareto Distribution (GPD). Pada penulisan makalah ini identifikasi curah hujan ekstrim di Derah Aliran Sungai (DAS) Brantas di Kabupaten Nganjuk dilakukan dengan pendekatan POT. Selanjutnya estimasi parameter GPD dilakukan menggunakan Model Bayesian Hierarchy $(\mathrm{MBH})$, distribusi prior yang digunakan dalam penelitian ini adalah conjugat prior. Hasil data curah hujan ekstrim dan hasil estimasi parameter GPD digunakan dalam perhitungan prediksi retun level curah hujan ekstrim dalam beberapa periode waktu ke depan di lima pos hujan DAS Brantas di Kabupaten Nganjuk yang diamati. Berdasarkan hasil yang didapat, dalam satu tahun ke depan di lima pos hujan yang diamati tidak terjadi hujan ekstrim, namun dalam tiga dan lima tahun ke depan terjadi curah hujan ekstrim.
\end{abstract}

Kata Kunci: Model Bayesian Hirarki, Return Level,Peaks Over Threshold

\begin{abstract}
Extreme rainfall is a very high or very low rainfall condition. One of the sciences that studies extreme events is the Peaks Over Threshold approach with distribution patterns following the Generalized Pareto Distribution. In writing this paper the identification of extreme rainfall in the Brantas River Basin in Nganjuk Regency was carried out using the Peaks Over Trheshold approach. Next, estimate the Generalized Pareto Distribution parameter. conducted using Bayesian Hierarchy Model, prior distribution used in this study is prior conjugate. The results of extreme rainfall data and the estimated parameters of the Generalized Pareto Distribution parameter. used in the calculation of predictions of the level of extreme rainfall in several periods of time ahead in five observed Brantas Watershed rain posts in Nganjuk District. Based on the results obtained, in the next year in five rain posts observed no extreme rain occurred, but in the next three and five years there was extreme rainfall.
\end{abstract}

Keywords: Bayesian Hierarchy Model, Return Level, Peaks Over Threshold

\section{Pendahuluan}

Letak geografis Indonesia yang berada pada $6^{\circ} \mathrm{LU}-11^{\circ} \mathrm{LS}$ dan $95^{\circ} \mathrm{BT}-141^{\circ} \mathrm{BT}$ menyebabkan Indonesia beriklim tropis. Indonesia memiliki iklim tropis lembab yang dipengaruhi angin monsun (monsoon) sehingga memiliki dua musim berbeda, yaitu musim 
kemarau dan musim penghujan. Rata-rata curah hujan tahunan sangat beragam, mulai kurang dari $1.000 \mathrm{~mm} /$ tahun di kawasan semi-arid tropik, 1.780-3.175 mm/tahun di dataran rendah, hingga $6.100 \mathrm{~mm} /$ tahun di kawasan pegunungan [1]. Perubahan iklim yang terjadi beberapa tahun terakhir mengakibatkan curah hujan ekstrim. Curah hujan ekstrim merupakan kondisi curah hujan yang sangat tinggi atau sangat rendah. Akibat curah hujan yang tinggi dan berkepanjangan menyebabkan air meluap di beberapa wilayah sekitar aliran Sungai Brantas sehingga petani mengalami gagal panen. Selain disebabkan oleh luapan air Sungai Brantas beberapa tanaman terkena penyakit dan membusuk akibat curah hujan yang tinggi. Puluhan hektar petani jagung di Desa Kaloran Kecamatan Ngronggot Nganjuk juga mengalami gagal panen akibat pohon jagung membusuk dampak kelebihan air dan disertai daun mengering sehingga mengganggu proses pertumbuhan. Setelah sebelumnya petani Tembakau di tiga Kecamatan yakni kecamatan Patianrowo, Lengkong dan Ngluyu terancam gagal panen [2]

Analisa kejadian ekstrim dapat dilakukan dengan metode Extrem Value Theory (EVT). Identifikasi nilai ekstrim dengan EVT dapat dilakukakan dengan dua pendekatan, yaitu pendekan Blox Maxima (BM) dengan pola distribusi mengikuti Generalized Extrem Value (GEV) dan pendekatan POT dengan pola distribusi data ekstrim mengikuti GPD. Karakteristik fungsi distribusi EVT dinyatakan oleh parameter lokasi $(\mu)$, skala atau scale $(\sigma)$, dan bentuk atau shape $(\xi)$. Hasil estimasi parameter dari masing-masing pendekatan tersebut kemudian digunakan untuk menghitung nilai return level [3].

Cooley dkk. [4] juga melakukan penelitian nilai ekstrim dengan menggunakan Model Bayesian Hirarki (MBH) dan hanya menggunakan faktor ketinggian (elevasi) lokasi pengamatan untuk mengelompokkan daerah pengamatan menjadi claster stasioner. Hanugraheni [5] selanjutnya juga melakukan penelitian curah hujan ekstrim. Dia menyatakan data curah hujan adalah data yang tersarang dalam wilayah tempat stasiun pengamatan itu berada. Data tersebut merupakan data dengan struktur hirarki dua tingkat dengan unit observasi di tingkat pertama adalah hari kejadian curah hujan ekstrim dan unit observasi pada tingkat kedua adalah stasiun pengamatan. Curah hujan ekstrim dimodelkan sebagai hasil dari kombinasi antara karakteristik curah hujan ekstrim harian dan wilayah tempat stasiun pengamatan berada. Ia melakukan penelitian pada curah hujan ekstrim di Jakarta dengan pendekatan POT menggunakan MBH. Pada penelitiannya digunakan distribusi improper non-konjugat dan non-informative prior. Hasil estimasi parameter menunjukkan bahwa modus dari variabel-variabelnya tidak berpengaruh signifikan terhadap perbedaan niali parameter shape, sehingga tidak berpengaruh pada hasil prediksi return level. 
Pada penulisan Makalah ini analisis curah hujan ekstrim dilakukan mengguakan POT dengan pola distribusi data ekstrim mengikuti GPD. Selanjutnya estimasi parameter GPD dilakukan menggunakan MBH. Identifikasi curah hujan ekstrim dan estimasi parameter digunakan untuk perhitungan retun level curah hujan ekstrim dalam periode waktu tertentu di DAS Brantas di Kabupaten Nganjuk.

\section{Metode Penelitian}

Data yang digunakan dalam penulisan Makalah ini adalah data sekunder pada data curah hujan bulanan tahun 2012 hingga tahun 2016 serta data lokasi stasiun pengamatan yang diperoleh dari Stasiun Geofisika Klas III Sawahan Nganjuk. Unit observasi yang digunakan dalam penulisan Makalah ini adalah lima pos hujan yang berada sekitar DAS Brantas Kabupaten Nganjuk, yang terdiri dari pos hujan Lengkong, Kertosono, Bangle, Tempuran, dan Lohgawe.

Variabel yang digunakan dalam penelitian ini diantaranya curah hujan (y), longitude atau lokasi berdasarkan garis bujur $\left(\mathrm{z}_{1}\right)$, latitude atau lokasi berdasarkan garis lintang $\left(z_{2}\right)$, elevasi atau ketinggian $\left(z_{3}\right)$, dan luas jangkauan pos hujan $\left(z_{4}\right)$.

Langkah-langkah analisis yang akan dilakukan berdasarkan tujuan dalam penulisan Makalah ini adalah sebagai berikut:

1. Langkah analisis untuk menyelesaikan tujuan penelitian yang pertama, yaitu mendapatkan sampel curah hujan ekstrim lima pos hujan di DAS Brantas di Kabupaten Nganjuk yang diamati dengan POT sebagai berikut:

a. Melakukan pra-pemrosesan data terhadap missing value data curah hujan di lima pos hujan yang diamati.

b. Mendeskripsikan data curah hujan dengan statistika deskriptif dan identifikasi pola sebaran curah hujan.

c. Mengidentifikasi distribusi data curah hujan di masing-masing pos hujan untuk mengetahui adanya distribusi data heavy tail dan nilai ekstrim dengan histogram dan normality plot.

d. Menentukan interval threshold dengan menggunakan metode Means Residual Life Plot (MRLP). Kemudian menentukan satu nilai threshold dengan metode persentil:

e. Pemeriksaan kesesuaian distribusi menggunakan probability plot dan quantile plot, sedangkan pengujian hipotesis dengan uji Kolmogorov-Smirnov. Jika data tidak memenuhi keseuaian data distribusi GPD maka kembali melakukan pengambilan data pada pos hujan lain. 
2. Langkah analisis untuk menyelesaikan tujuan penelitian yang kedua, yaitu memperoleh hasil estimasi parameter GPD dengan MBH untuk prediksi return level curah hujan ekstrim di DAS Brantas di Kabupaten Nganjuk.

a. Mendapatkan penaksiran parameter MBH dua tingkat:

b. Melakukan perhitungan return level untuk beberapa periode waktu.

c. Menginterpretasikan hasil return level.

d. Menarik kesimpulan.

\section{Hasil dan Pembahasan}

Analisis dan pembahasan mendapatkan curah hujan esktrim menggunakan POT dan estimasi parameter GPD dengan MBH pada data curah hujan ekstrim lima pos hujan yang diamati di DAS Brantas di Kabupaten Nganjuk dijelaskan sebagai berikut:

\section{A. Pengambilan Sampel Data Ekstrim dengan POT}

Sebelum pengambilan sampel data ekstrim terlebih dahulu dilakukan analisa berkaitan dengan data iklim, yaitu tahap pra-pemrosesan data. Pra-pemrosesan data merupakan langkah dalam identifikasi data terhadap missing value dan trace atau tidak terukur (TTU) akibat kerusakan alat ukur, meskipun terjadi hujan namun tidak dapat dilakukan pengukuran. Berikut tabel yang menyajkan informasi tentang missing value dan TTU.

Tabel 1. Identifikasi Missing Value dan TTU Data Curah Hujan

\begin{tabular}{ccccc}
\hline Tim & TTU & $\begin{array}{c}\text { \% } \\
\text { TTU }\end{array}$ & $\begin{array}{c}\text { Missing } \\
\text { Value }\end{array}$ & $\begin{array}{c}\% \\
\text { Missing } \\
\text { Value }\end{array}$ \\
\hline Lengkong & 7 & 0,12 & 12 & 0,20 \\
Kertosono & 7 & 0,12 & 14 & 0,23 \\
Bangle & 7 & 0,12 & 12 & 0,20 \\
Tempuran & 7 & 0,12 & 14 & 0,23 \\
Lohgawe & 7 & 0,12 & 14 & 0,23 \\
\hline
\end{tabular}

Berdasarkan Tabel 1 diketahui bahwa dari lima pos hujan yang diamati memiliki curah hujan tak terukur atau TTU sebanyak 7 pengamatan dari 60 pengamatan atau sebesar 0,12 persen. Selain itu, dari lima pos hujan yang diamati memiliki missing value sebanyak 12 hingga 14 pengamatan dari 60 pengamatan atau sebesar 0,20 hingga 0,23 persen. Selanjutnya nilai TTU diimputasi dengan nilai 0 (nol) dan missing value dimasukkan dengan rata-rata curah hujan bulanan di stasiun yang datanya tersedia di waktu yang sama dengan missing value. 
Setelah dilakukan pra-pemrosesan data, dilakukan analisis menggunakan statistika deskriptif. Tabel 2 merupakan hasil statistika deskriptif di lima pos hujan yang diamati.Dari Tabel 2 dapat diketahui bahwa dari lima pos hujan yang diamati rata-rata curah hujan bulanan tertinggi ada pada Pos Hujan Tempuran yaitu mencapai 154,4 mm per bulan, sedangkan curah hujan bulanan tertinggi ada pada Pos Hujan Kertosono yaitu sebesar $633 \mathrm{~mm}$ per bulan.

Tabel 2. Statistika Deskriptif Curah Hujan Bulanan (mm)

\begin{tabular}{lcccccr}
\hline $\begin{array}{c}\text { Stasiun } \\
\text { Pengamatan }\end{array}$ & $\begin{array}{c}\text { Rata- } \\
\text { Rata }\end{array}$ & $\begin{array}{c}\text { Vari- } \\
\text { ansi }\end{array}$ & Min & Maks & Median & Mode \\
\hline Lengkong & 129,8 & 14866 & 0 & 466 & 122,5 & 0 \\
Kertosono & 146,8 & 22536 & 0 & 633 & 108,5 & 0 \\
Bangle & 136,6 & 15815 & 0 & 516 & 107 & 0 \\
Tempuran & 154,4 & 18998 & 0 & 483 & 129,8 & 0 \\
Lohgawe & 151,6 & 18938 & 0 & 514 & 131 & 0 \\
\hline
\end{tabular}

Keterangan:

Min $=$ Minimum, Maks $=$ Maksimum, Mode $=$ Modus

Selanjutnya identisikasi untuk mengetahui pola curah hujan bulanan dengan menggunakan bar chart yang disajikan dalam Gambar 1. Seperti ditunjukkan dalam Gambar 1, bahwa pola curah hujan bulanan di Pos Hujan Lengkog menunjukkan pola curah hujan monsoon. Pola curah hujan di empat pos hujan lainnya juga menunjukkan pola curah hujan monsun.

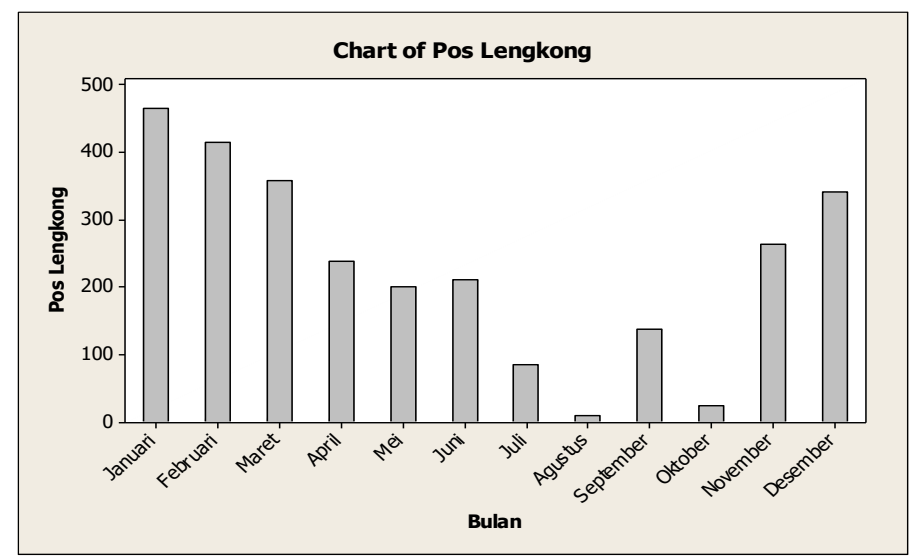

Gambar 1. Pola Curah Hujan Bulanan di Pos Hujan Lengkong

Seperti ditunjukkan dalam Gambar 1, bahwa pola curah hujan bulanan di Pos Hujan Lengkog menunjukkan pola curah hujan monsoon. Pola curah hujan di empat pos hujan lainnya juga menunjukkan pola curah hujan monsun. Pola distribusi data curah hujan juga dapat diidentifikasi dengan nilai skewness dan kurtosis. 
Tabel 3 menunjukkan bahwa nilai skewness pada masing-masing lima pos hujan yang diamati bernilai lebih dari 0 (nol) yang berarti bahwa distribusi curah hujan tidak simetris atau ekor lebih memanjang ke kanan. Demikian pula dengan histogram curah hujan harian di lima pos hujan yang diamati, sehingga dapat dilakukan analisis lebih lanjut dengan EVT. Histogram curah hujan bulanan Pos Hujan Lengkong disajikan pada Gambar 2.

Table 3 Skewness dan Kurtosis

\begin{tabular}{lc}
\hline $\begin{array}{c}\text { Stasiun } \\
\text { Pengamatan }\end{array}$ & Skewness \\
\hline Lengkong & 0,82 \\
Kertosono & 1,35 \\
Bangle & 0,91 \\
Tempuran & 0,72 \\
Lohgawe & 0,89 \\
\hline
\end{tabular}

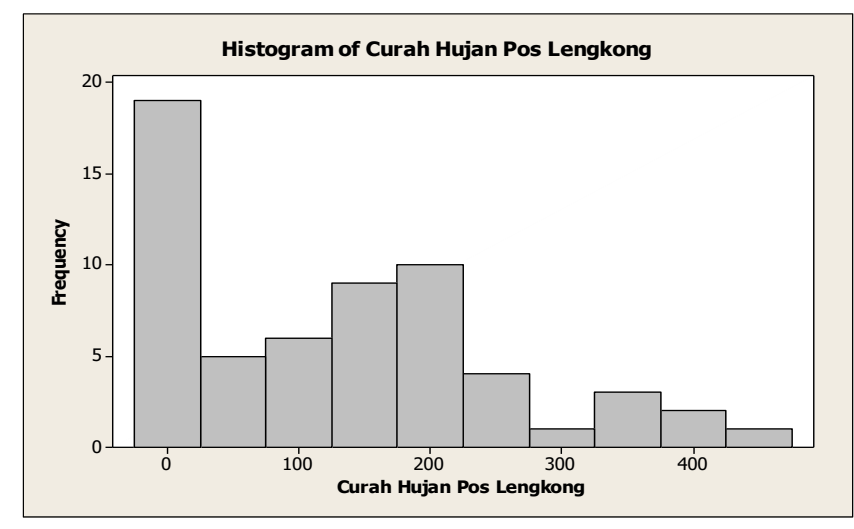

Gambar 2. Histogram Curah Hujan Bulanan Pos Hujan Lengkong

Penentuan ambang batas harus memperhatikan banyaknya amatan yang melampaui ambang batas dan pendekatan garis linier yang konsisten setelah ambang batas. Gambar 3 berikut merupakan grafik MRLP untuk curah hujan bulanan pos hujan Lengkong. 


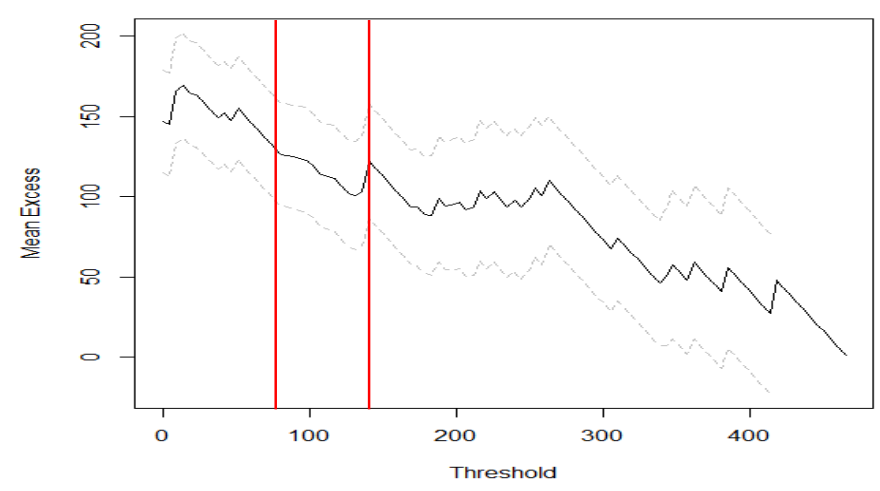

Gambar 3. MRLP Curah Hujan Bulanan Pos Hujan Lengkong

Grafik MRLP Pos Hujan Lengkong menunjukkan grafik menurun secara konsisten setelah threshold $u \approx 270$, namun hanya ada 7 amatan yang melampaui threshold. Selanjutnya pada $u \approx$ 140, grafik juga menurun secara konsisten dan terdapat 22 data amatan yang melampaui threshold. Sehingga $u \approx 140$ dianggap sebagai letak nilai threshold. Selanjutnya dilakukan pengujan kestabilan (berpola linier) dengan grafik modified scale dan shape parameter plot untuk mendukung pemilihan threshold dengan grafik MRLP. Grafik modified scale dan shape parameter plot disajikan dalam Gambar 4 berikut:
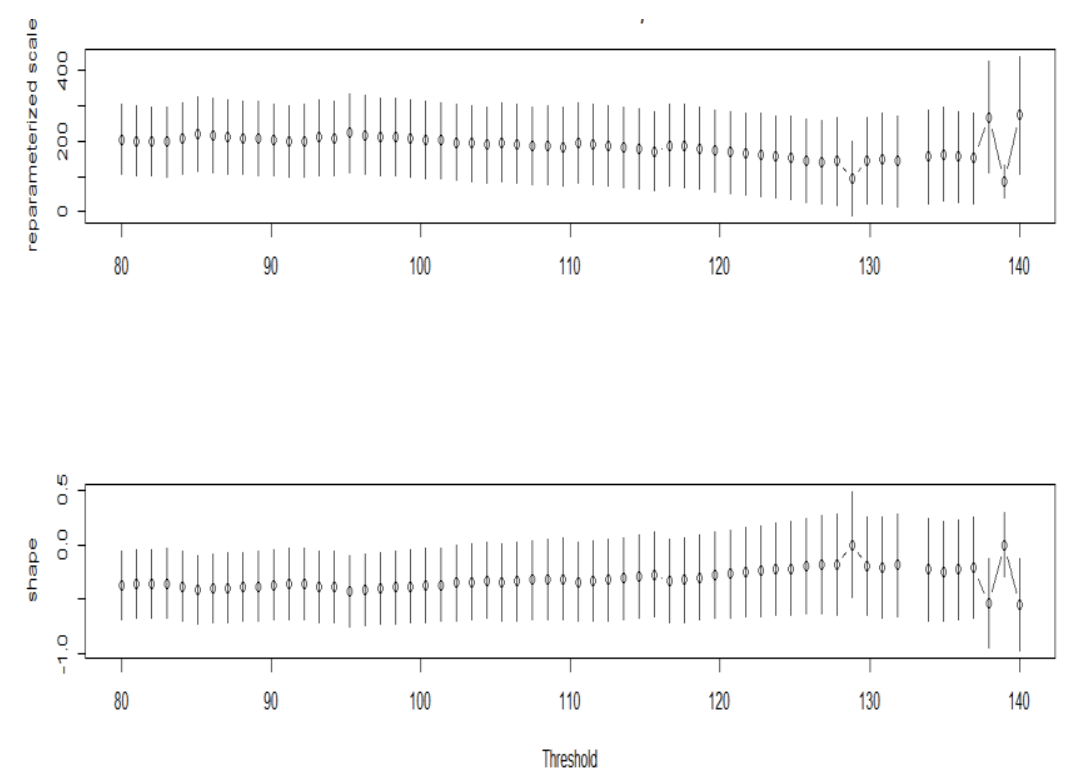

Gambar 4. Modified scale dan Shape Parameter Plot Curah Hujan Pos Hujan Lengkong

Berdasarkan Gambar 3 dan Gambar 4 dapat disimpulkan bahwa nilai threshold Pos Hujan Lengkong terletak pada interval threshold $u=[80,137]$. Namun karena nilai yang diperoleh berupa interval dan penentuan suatu nilai threshold berdasarkan subjektifitas peneliti, pengambilan threshold pada interval tersebut dilakukan menggunakan metode persentil, yaitu 
dengan cara mengambil $60 \%$ dari keseluruhan data yang telah diurutkan dari nilai terbesar hingga terkecil. Pengambilan $60 \%$ dari data dikarenakan data yang diidentifikasi sebagai curah hujan ekstrim berada pada interval tersebut. Berdasarkan rumus metode persentil pada Persamaan 2 didapatkan nilai $u=137$ dan banyak data amatan yang melebihi nilai $u=137$ sebanyak 22 data amatan. Pengambilan sampel data ekstrim dengan MRLP dan metode persentil untuk empat pos hujan lain yang diamati disajikan dalam Tabel 4.

Selanjutnya, dilakukan pemeriksaan kesesuaian distribusi untuk mengetahui adanya kesesuaian distribusi data curah hujan ekstrim bulanan dengan distribusi teoritis, yaitu GPD. Pemeriksaan distribusi secara visual dilakukan dengan menggunakan probability plot dan quantile plot, sedangkan pengujian formal dilakukan dengan menggunakan uji KolmogorovSmirnov. Hasil pemeriksaan secara visual curah hujan ekstrim bulanan pos hujan Lengkong disajikan pada Gambar 5. Berdasarkan Gambar 5 diketahui bahwa pada probablity plot maupun quantile plot sebagian besar sebaran titik (data curah hujan ekstrim) mengikuti garis linier, sehingga dapat disimpulkan bahwa data curah hujan ekstrim bulanan mengikuti GPD.

Table 4. Nilaii Threshold

\begin{tabular}{lccc}
\hline Pos Hujan & $\boldsymbol{N}$ & $\boldsymbol{u}(\mathbf{m m})$ & $\boldsymbol{n}_{\boldsymbol{u}}$ \\
\hline Lengkong & 60 & 137 & 22 \\
Kertosono & 60 & 130 & 24 \\
Bangle & 60 & 148 & 23 \\
Tempuran & 60 & 153 & 24 \\
Lohgawe & 60 & 143 & 24 \\
\hline
\end{tabular}

Keterangan:

$\mathrm{N}=$ Banyak Pengamatan $u=$ Nilai Threshold

$n_{u}=$ Banyak Sampel Ekstrim
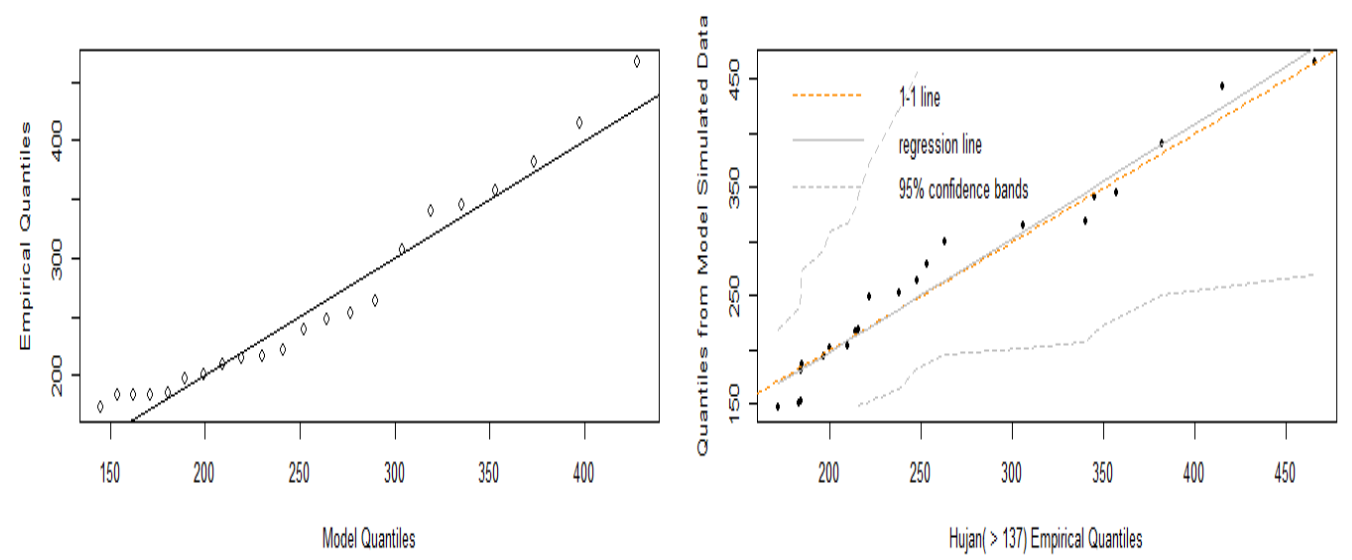

Gambar 5. Probability Plot dan Quantile Plot GPD Pos Hujan Lengkong 
Tabel 5 menunjukkan bahwa semua pos hujan yang diamati memiliki $D_{\text {hitung }}$ yang lebih kecil dibandingkan $D_{\alpha}$ sehingga gagal tolak $\mathrm{H}_{0}$ dengan kesimpulan semua data curah ekstrim bulanan di lima pos hujan yang diamati mengikuti GPD. Sehingga proses analisis EVT dapat dilanjutkan.

Tabel 5. Hasil Uji Kolmogorov-Smirnov GPD

\begin{tabular}{lcccc}
\hline \multicolumn{1}{c}{$\begin{array}{c}\text { Pos } \\
\text { Hujan }\end{array}$} & $\mathbf{n}_{\mathbf{u}}$ & $\mathbf{D}_{\text {hitung }}$ & $\mathbf{D}_{\boldsymbol{\alpha}, \text { nu }}$ & Keputusan \\
\hline Lengkong & 22 & 0.183 & 0.281 & Gagal Tolak H0 \\
Kertosono & 24 & 0.218 & 0.269 & Gagal Tolak H0 \\
Bangle & 23 & 0.152 & 0.275 & Gagal Tolak H1 \\
Tempuran & 24 & 0.129 & 0.269 & Gagal Tolak H2 \\
Lohgawe & 24 & 0.171 & 0.275 & Gagal Tolak H3 \\
\hline
\end{tabular}

Keterangan:

$\mathrm{n}_{\mathrm{u}}=$ Banyak pengamatan yang melebihi threshold $\alpha=0.05$

\section{B. Estimasi Parameter GPD dan Prediksi Return Level}

Estimasi parameter GPD di lima pos hujan di DAS Brantas di Kabupaten Nganjuk dilakukan menggunakan Metode Bayesian Hirarki. Estimasi parameter GPD dengan pendekatan Bayesian dimulai dengan tahap pembentukan struktur parameter berdasarkan bentuk fungsi rangkaian variabel bebas yang dianggap mempengaruhi parameter GPD. Visualisasi model dilakukan dengan Directed Acyclic Graph (DAG). Berikut DAG MBH dua tingkat untuk data curah hujan ekstrim di lima pos hujan yang diamati.

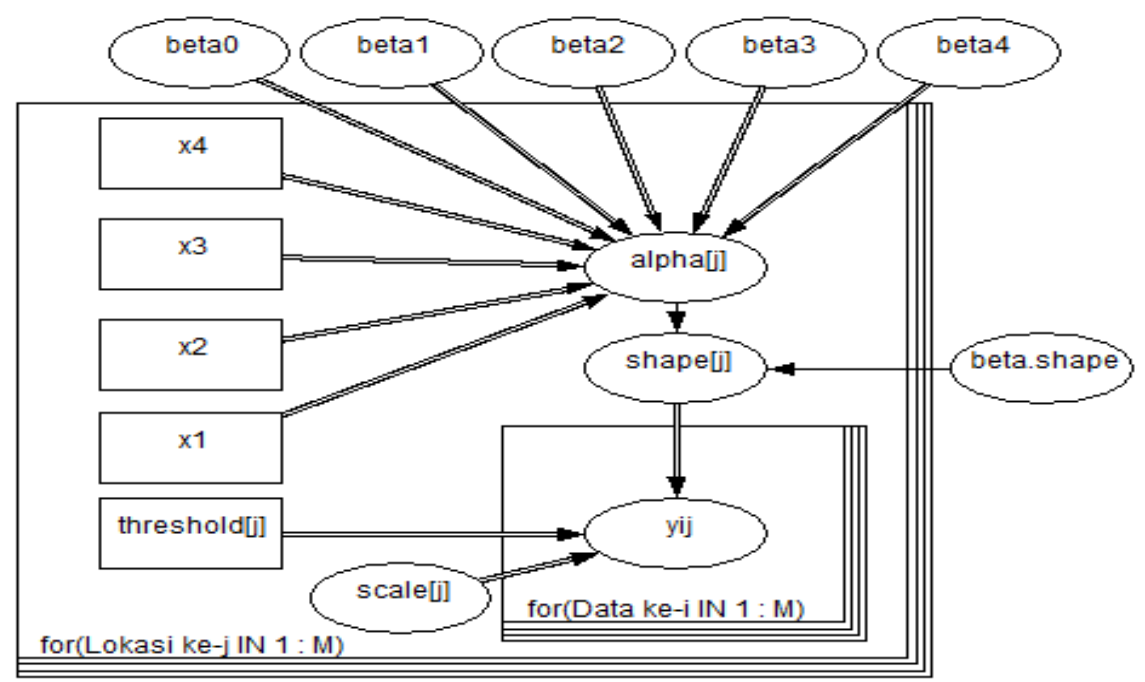

Gambar 6. DAG MBH Dua Tingkat Data Curah Hujan Ekstrim

Gambar 6 menunjukkan bahwa $y$ merupakan data curah hujan ekstrim sebanyak $i$ pengamatan untuk setiap pos hujan $j$. Berdasarkan hasil pengujian kesesuaian distribusi, curah 
hujan ekstrim di setiap pos hujan yang diamati $\left(y_{i j}\right)$ berdistribusi GPD dengan tiga parameter, yaitu $u, \sigma$, dan $\xi$. Sehingga himpunan parameter GPD tingkat pertama untuk setiap pos hujan ke$j$ dapat ditulis sebagai $\theta=\left(u_{j}, \sigma_{j}, \xi_{j}\right)$. Nilai parameter $u$ untuk setiap pos hujan yang diamati adalah sama dengan nilai threshold, sedangkan nilai $\sigma$ dan $\xi$ berbeda-beda di setiap pos hujan yang diamati. Nilai parameter $\xi$ merupakan parameter yang menyatakan bentuk ekor distribusi GPD, sehingga nilai $\xi$ dapat menjelaskan pola perilaku pengamatan ekstrim di setiap pos hujan yang diamati. Nilai parameter $\xi$ dianggap dipengaruhi oleh beberapa faktor, seperti $z_{1}$ (longitude atau lokasi berdasarkan garis bujur), $z_{2}$ (latitude atau lokasi berdasarkan garis lintang), $z_{3}$ (elevasi atau ketinggian), dan $z_{4}$ (luas jangkauan pos hujan). Dengan demikian, parameter $\xi$ memiliki himpunan parameter $\gamma_{\xi_{j}}, \beta_{0}, \beta_{1}, \beta_{2}, \beta_{3}$, dan $\beta_{4}$ sebagai hyperparameter pada tingkat kedua, yang merupakan parameter distribusi prior $\xi$ dan parameter regresi dari parameter prior $\xi$. Pada penulisan Makalah ini penentuan distribusi prior menggunakan prior conjugat atau prior sekawan, yaitu distribusi prior yang digunakan masih dalam satu keluarga distribusi dengan pola distribusi likelihood data yang didapat. Berikut didapatkan distribusi posterior dari parameter skala $(\sigma)$ dan parameter bentuk $(\xi)$ :

$$
\begin{aligned}
f\left(\sigma_{j} \mid y\right)=\frac{\frac{1}{\sigma_{j}^{\alpha+1+\frac{n}{\xi}}} \prod_{i=1}^{n}\left(1+\frac{\sigma_{j} y_{i}^{-1}}{\xi}\right)^{-\frac{1}{\xi}-1}}{\int_{-\infty}^{\infty} \frac{1}{\sigma_{j}^{\alpha+1-\frac{n}{\xi}}} \prod_{i=1}^{n}\left(1+\frac{\sigma_{j} y_{i}^{-1}}{\xi}\right)^{-\frac{1}{\xi}-1} d \sigma} \\
f\left(\xi_{j} \mid y\right)=\frac{\frac{1}{\xi^{K_{1}+n+\frac{n}{\xi}}} \prod_{i=1}^{n}\left(1+\frac{\sigma_{i}^{-1}}{\xi}\right)^{-\frac{1}{\xi}-1}}{\frac{1}{\xi^{K_{1}+n+\frac{n}{\xi}}} \int_{-\infty}^{\infty} \prod_{i=1}^{n}\left(1+\frac{\sigma_{i}^{-1}}{\xi}\right)^{-\frac{1}{\xi}-1} d \xi}
\end{aligned}
$$

Distribusi posterior yang diperoleh digunakan untuk estimasi parameter. Estimasi parameter merupakan ekspektasi dari distribusi posterior.

$$
E\left(\sigma_{j} \mid y\right)=\int_{-\infty}^{\infty} \sigma \frac{\frac{1}{\sigma_{j}^{\alpha+1-\frac{n}{\xi}}} \prod_{i=1}^{n}\left(1+\frac{\sigma_{j} y_{j}^{-1}}{\xi}\right)^{-\frac{1}{\xi}-1}}{\int_{-\infty}^{\infty} \frac{1}{\sigma_{j}^{\alpha+1-\frac{n}{\xi}}} \prod_{i=1}^{n}\left(1+\frac{\sigma_{j} y_{j}^{-1}}{\xi}\right)^{-\frac{1}{\xi}-1} d \sigma} d \sigma
$$




$$
E\left(\xi_{j} \mid y\right)=\int_{-\infty}^{\infty} \frac{\frac{1}{\xi^{K_{1}+n+\frac{n}{\xi}}} \prod_{i=1}^{n}\left(1+\frac{\sigma y_{i}^{-1}}{\xi}\right)^{-\frac{1}{\xi}-1}}{\frac{1}{\xi^{K_{1}+n+\frac{n}{\xi}}} \int_{-\infty}^{\infty} \prod_{i=1}^{n}\left(1+\frac{\sigma_{i}^{-1}}{\xi}\right)^{-\frac{1}{\xi}-1} d \xi} d \xi
$$

Karena pada Persamaan (3) dan (4) masih mengandung nilai parameter yang belum diketahui dan distribusi posterior yang telah diperoleh infisible maka estimasi parameter skala $\sigma$ dan bentuk $\xi$ dilakukan dengan metode Markov Chain Monte Carlo (MCMC) menggunakan software OpenBUGS.

Nilai estimasi parameter dalam MBH diperoleh dari distribusi posterior dengan proses pengambilan sampel parameter dilakukan menggunakan metode MCMC dan Gibss Sampling. Pada penulisan Makalah ini prosedur MCMC dilakukan sebanyak 1.000.000 iterasi untuk mendapatkan sampel paraeter dari distribusi posterior. Setelah pengambilan sampel dilakukan, maka dilakukan diagnosa untuk mengetahui kesesuaian hasil estimasi dengan sifat-sifat Markov Chain yang strongly ergodic dan konvergen.

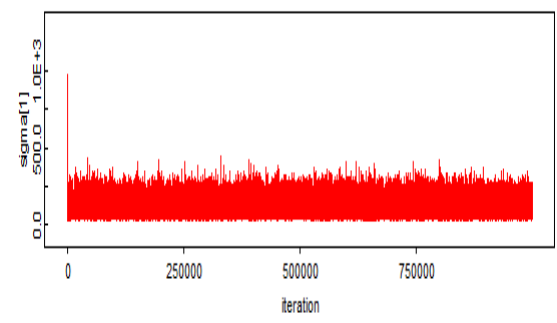

(a)

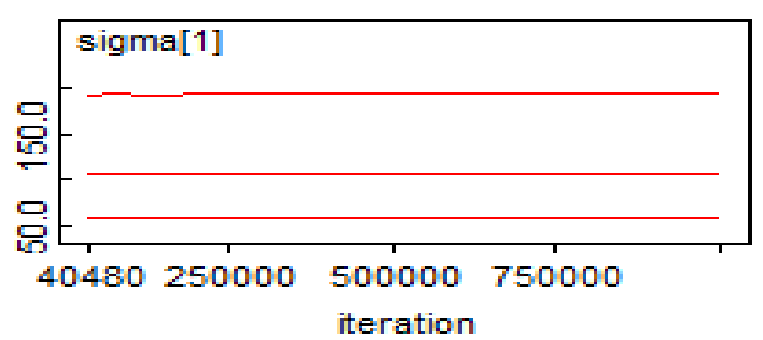

(b)

Gambar 7. Plot Diagnostik Kekonvergenan (a) Serial Plot, (b) Running Qantiles Plot

Gambar 7(a) pola yang konstan yang bersifat stasioner dan random. Gambar 7(b) menunjukkan bahwa proses pengambilan sampel memenuhi sifat ergodic mean dimana nilai yang dihasilkan telah mencapai nilai yang stabil. Oleh karena itu, berdasarkan Gambar 7(a) dan Gamber 7(b) tidak menunjukkan pola tertentu maka dapat dikatakan bahwa proses iterasi telah mencapai kondisi equilibrium atau konvergen.

Selanjutnya dilakukan pengujian parameter hasil estimasi dengan $\mathrm{MBH}$ untuk masingmasing parameter. Tabel 6 memberikan informasi bahwa parameter regresi $\hat{\beta}_{0}, \hat{\beta}_{1}, \hat{\beta}_{2}, \hat{\beta}_{3}$, dan $\hat{\beta}_{4}$ menunjukkan hasil yang baik karena nilai MC error lebih kecil dari 5\% standar deviasi hasil estimasi parameter tersebut sehingga berpengaruh signifkan terhadap parameter $\xi$. Hal ini menunjukkan bahwa nilai $\xi$ untuk masing-masing pos hujan dipengaruhi oleh faktor $x_{1}, x_{2}, x_{3}$, dan $x_{4}$. Hasil estimasi parameter skala $(\sigma)$ dan parameter bentuk $(\xi)$ di masing-masing pos hujan 
menunjukkan hasil yang baik karena nilai MC error lebih besar dari 5\% hasil estimasi parameter tersebut.

Tabel 6. Estimasi Parameter MBH

\begin{tabular}{crrrrrr}
\hline Parameter & $\begin{array}{c}\text { Rata- } \\
\text { Rata }\end{array}$ & $\begin{array}{c}\text { Standar } \\
\text { Deviasi }\end{array}$ & $\begin{array}{c}\text { MC } \\
\text { Error }\end{array}$ & $\mathbf{2 , 5 \%}$ & Median & $\mathbf{9 7 , 5 \%}$ \\
\hline$\hat{\beta}_{0}$ & 6,918 & 9,152 & 0,226 & 2,05 & 3,78 & 34,99 \\
$\hat{\beta}_{1}$ & 13,980 & 25,820 & 0,762 & 2,08 & 5,97 & 85,79 \\
$\hat{\beta}_{2}$ & 18,330 & 26,550 & 0,720 & 5,09 & 9,65 & 87,76 \\
$\hat{\beta}_{3}$ & 4,398 & 8,108 & 0,215 & 1,02 & 1,95 & 24,93 \\
$\hat{\beta}_{4}$ & 5,111 & 13,710 & 0,391 & 1,02 & 1,93 & 31,25 \\
$\hat{\xi}_{1}$ & 1,001 & 0,001 & 0,000 & 1,00 & 1,00 & 1,00 \\
$\hat{\xi}_{2}$ & 1,001 & 0,001 & 0,000 & 1,00 & 1,00 & 1,00 \\
$\hat{\xi}_{3}$ & 1,001 & 0,001 & 0,000 & 1,00 & 1,00 & 1,00 \\
$\hat{\xi}_{4}$ & 1,001 & 0,001 & 0,000 & 1,00 & 1,00 & 1,00 \\
$\hat{\xi}_{5}$ & 1,001 & 0,001 & 0,000 & 1,00 & 1,00 & 1,00 \\
$\hat{\sigma}_{1}$ & 110,900 & 35,550 & 0,042 & 57,03 & 105,70 & 194,80 \\
$\hat{\sigma}_{2}$ & 114,100 & 36,970 & 0,043 & 58,16 & 108,70 & 201,60 \\
\hline \multirow{2}{*}{ Parameter } & Rata- & Standar & MC & $\mathbf{2 , 5 \%}$ & Median & $\mathbf{9 7 , 5 \%}$ \\
\hline$\hat{\sigma}_{3}$ & Rata & Deviasi & Error & & & \\
$\hat{\sigma}_{4}$ & 94,590 & 31,280 & 0,038 & 47,56 & 89,87 & 168,70 \\
$\hat{\sigma}_{5}$ & 97,870 & 32,760 & 0,038 & 48,80 & 92,89 & 175,70 \\
& 105,400 & 35,100 & 0,042 & 52,69 & 100,10 & 188,80 \\
\hline
\end{tabular}

Nilai estimasi parameter yang diperoleh dengan $\mathrm{MBH}$ digunakan untuk menghitung nilai return level. Berdasarkan Persamaan 8 diperoleh nilai return level sebagai berikut.

Tabel 7. Prediksi Return Level

\begin{tabular}{|c|c|c|c|c|c|c|}
\hline \multirow[b]{2}{*}{$\begin{array}{c}\text { Pos } \\
\text { Hujan }\end{array}$} & \multirow[b]{2}{*}{$\boldsymbol{u}$} & \multirow[b]{2}{*}{$\widehat{\sigma}$} & \multirow[b]{2}{*}{$\widehat{\xi}$} & \multicolumn{3}{|c|}{ Return Level } \\
\hline & & & & $\begin{array}{c}1 \\
\text { tahun }\end{array}$ & $\begin{array}{c}3 \\
\text { tahun }\end{array}$ & $\begin{array}{c}5 \\
\text { tahun }\end{array}$ \\
\hline Lengko & 137 & 110,9 & 1,001 & 66,79 & 148,09 & 229,45 \\
\hline Kertosono & 130 & 114,1 & 1,001 & 61,56 & 152,82 & 244,14 \\
\hline Bangle & 148 & 94,59 & 1,001 & 89,69 & 162,19 & 234,73 \\
\hline Tempuran & 153 & 97,87 & 1,001 & 94,30 & 172,57 & 250,90 \\
\hline Lohgawe & 143 & 105,4 & 1,001 & 79,78 & 164,08 & 248,44 \\
\hline
\end{tabular}

Tabel 7. memberikan informasi mengenai return level, yaitu suatu level kejadian ekstrem yang akan terlampaui rata-rata sekali dalam suatu periode waktu tertentu dimana probabilitas terjadinya sebesar 1/T. Nilai return level Pos Hujan Lengkong pada periode satu tahun ke depan adalah sebesar 66,79 mm. Hal ini menunjukkan bahwa pada tahun 2017 terdapat kemungkinan sebesar 1/1 atau dapat dipastikan terjadi curah hujan yang melebihi level 66,79 mm rata-rata satu kali pada periode satu tahun. Namun curah hujan sebesar $66,79 \mathrm{~mm}$ bukanlah tergolong curah 
hujan ekstrim jika dibandingkan dengan tahun sebelumnya. Pada periode tiga tahun atau pada tahun 2019 terdapat kemungkinan sebesar 1/3 atau 0,33 curah hujan ekstrim yang melebihi level 148,09 mm rata-rata satu kali pada periode lima tahun di Pos Hujan Lengkong. Pada periode lima tahun atau pada tahun 2021 terdapat kemungkinan sebesar 1/5 atau 0,2 curah hujan ekstrim yang melebihi level 944,3294 mm rata-rata satu kali pada periode lima tahun di Pos Hujan Lengkong.

\section{Simpulan}

Dari hasil pembahasan yang telah disajikan dapat disimpulkan:

1. Curah hujan ekstrim di lima pos hujan yang diamati di DAS Brantas di Kabupaten Nganjuk yang didapatkan dengan pendakatan POT bahwa nilai threshold paling kecil berada pada Pos Hujan Kertosono, yaitu sebesar $130 \mathrm{~mm}$. Sedangkan threshold paling tinggi berada pada Pos Hujan Tempuran, yaitu sebesar $153 \mathrm{~mm}$.

2. Hasil estimasi parameter GPD menunjukkan bahwa parameter $\beta_{0}, \beta_{1}, \beta_{2}, \beta_{3}$, dan $\beta_{4}$ yang merupakan parameter regresi dari variabel $x_{1}, x_{2}, x_{3}$, dan $x_{4}$ berpengaruh signifikan. Hal ini bahwa nilai $\xi$ untuk masing-masing pos hujan dipengaruhi oleh faktor $x_{1}, x_{2}, x_{3}$, dan $x_{4}$. Hasil estimasi parameter skala $(\sigma)$ dan parameter bentuk $(\xi)$ di masing-masing pos hujan menunjukkan hasil yang baik karena nilai MC error lebih kecil dari 5\% dari standar deviasi hasil estimasi parameter tersebut. Hasil perhitungan nilai return level periode satu tahun semua pos hujan yang diamati mempunyai nilai return level rendah yang dikategorikan sebagai bukan curah hujan ekstrim jika dibandingkan dengan tahun sebelumnya, periode tiga tahun dan lima tahun semua pos hujan yang diamati mempunyai nilai return level rendah yang dikategorikan sebagai curah hujan ekstrim jika dibandingkan dengan tahun sebelumnya. Nilai return level terbesar untuk semua periode terletak pada Pos Hujan Tempuran yang masing-masing berilai $94,30 \mathrm{~mm}, 172,57 \mathrm{~mm}$, dan 250,90 mm.

\section{Daftar Pustaka}

[1] Tim Penyusun, About Jakarta and Depok. Depok: Universitas Indonesia, 2004.

[2] Berita Metro, “Anomali Cuaca Banyak Petani Gagal Panen,” 2016. [Online]. Available: http://m.beritametro.news/nganjuk/anomali-cuaca-banyak-petani-gagal-panen. [Accessed: 15-Jan-2017].

[3] A. J. Mcneil, "Extreme Value Theory for Risk Managers," Intern. Model. CAD II, 1999.

[4] D. Cooley, D. Nychka, and P. Naveau, "Bayesian spatial modeling of extreme precipitation return levels," J. Am. Stat. Assoc., 2007. 
[5] J. S. I. Hanugraheni and N. Irawan, "Pemodelan Bayesian Hirarki Data Curah Hujan Ekstrim di Jakarta,” J. Sains dan Seni ITS2, vol. 5, no. 1, 2016. 